[Note]

\title{
New Records of Marine Rhodophyta from the Pacific Coast of Mexico
}

\author{
Raúl Aguilar-Rosas ${ }^{1 *}$, Luis E. Aguilar-Rosas ${ }^{2}$, Luz Elena Mateo-Cid $^{3}$ and \\ Catalina Mendoza-González ${ }^{3}$ \\ ${ }^{1}$ Facultad de Ciencias Marinas, Universidad Autónoma de Baja California, km 107 Carretera Tijuana Ensenada, \\ Ensenada, Baja California. C.P. 22830, México \\ ${ }^{2}$ Instituto de Investigaciones Oceanológicas, Universidad Autónoma de Baja California, km 107 Carretera Tijuana Ensenada, \\ Ensenada, Baja California. C.P. 22830, México \\ ${ }^{3}$ Departamento de Botánica, Escuela Nacional de Ciencias Biológicas, Instituto Politécnico Nacional, \\ Prolongación Carpio y Plan de Ayala, D.F. 11340, México
}

\begin{abstract}
Two species of marine red algae, Jania ungulata (Yendo) Yendo f. brevior (Yendo) Yendo and Peyssonnelia japonica (Segawa) Yoneshigue (Rhodophyta) were collected for the first time from Mexican Pacific coast. Their vegetative and reproductive structures are described, as well as the habitat where they were found and their geographical distribution along the Pacific coasts of Mexico. Jania ungulata f. brevior is a commonly growing epiphytic and Peyssonnelia japonica is epiphyte. The fact that we found this new records in Mexican coast is noteworthy, due that this species are originally described in Japanese coast. The absence of records of this species in the Mexican coast is likely related in part to the lack of specific collections and the fact that the specimens are small and delicate, and may commonly be unnoticed during samplings.
\end{abstract}

Key Words: Jania ungulata f. brevior, Pacific Mexico, Peyssonnelia japonica, Rhodophyta

\section{INTRODUCTION}

The number of species of marine algae registered for the Mexican Pacific coast is 1108 (Pedroche and Sentíes 2003a). In particular the western coast of the Peninsula of Baja California, is one of the most studied and the one than it shows the greater number of species (742 taxa), in comparison with the region of the Gulf of California with 669 and the Mexican Tropical Pacific with 444 species (Pedroche and Sentíes 2003b). However, the knowledge of marine algae in the Mexican Pacific has been increased in recent years, with the records and descriptions of new species (Broom et al. 2002; Pedroche and Sentíes 2003; Aguilar-Rosas et al. 2004; Aguilar-Rosas et al. 2005; Mateo-Cid et al. 2005). The marine floral inventory is still incomplete and more complete surveys are still needed in understudies and more remote locations.

This study provides the first record of two species from the Mexican Pacific coast including the states of Baja California Sur, Sonora, Jalisco, Colima, Guerrero

*Corresponding author (raguilar@uabc.mx) and Oaxaca. The species are Jania ungulata (Yendo) Yendo f. brevior (Yendo) Yendo and Peyssonnelia japonica (Segawa) Yoneshigue (Rhodophyta). These records are based on collections conducted between 1970 and 1998 . The vegetative and the reproductive structures of these species have been studied.

\section{MATERIALS AND METHODS}

Thallus were collected from the intertidal zone in several locations along the Mexican Pacific coast that include the states of Baja California Sur, Sonora, Colima, Guerrero and Oaxaca, during 1970-1998 (Fig. 1). Collections were fixed with $4 \%$ formalin seawater solution in the field. Preserved specimens were sectioned and stained with blue aniline for anatomical examination using light microscopy. The specimens were decalcified with $0.6 \mathrm{M} \mathrm{HNO}_{3}$ and dehydrated with ethyl alcohol. Small segments were embedded in paraffin, cut into sections 9-10 $\mu \mathrm{m}$ thick with a manual microtome, fixed on slides with Ruyter's adhesive (Martoja and MartojaPierson, 1970), and stained with blue aniline and hematoxylin-eosine. Observation and photomicrography were 


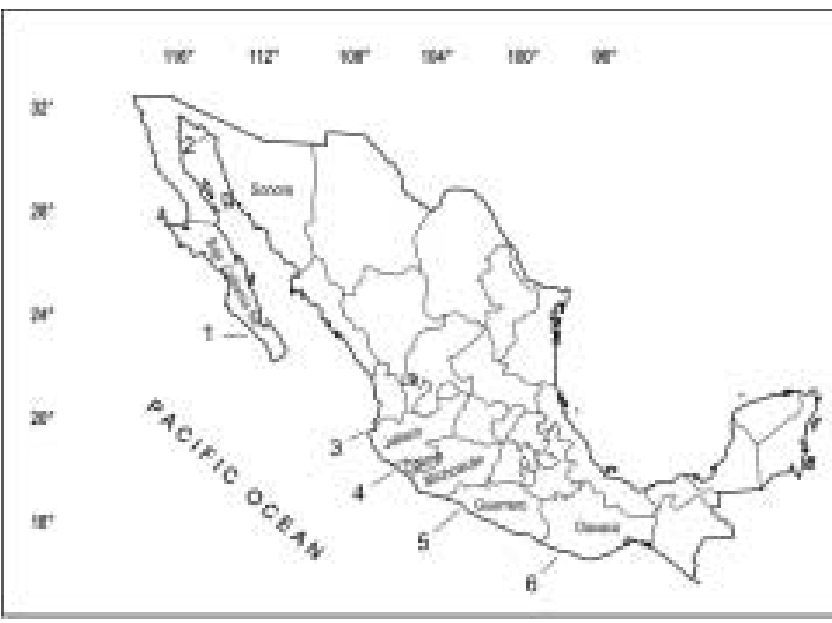

Fig. 1. Map showing the study area and collections sites. 1) Punta Conejo; 2) Puerto Peñasco; 3) El Corral; 4) Playa La Audiencia; 5) Playa Las Gatas; 6) Playa Santa Elena.

conducted using a digital camera (Sony DSC-S85, Tokyo, Japan) connected to a Zeiss microscope (Axioscop 40, Goettingen, Germany). The figures were edited using Adobe ${ }^{\circledR}$ Photoshop ${ }^{\circledR} 7.0$ (Adobe Systems Inc., San Jose, USA). Specimens examined were deposited in the herbarium (ENCB) of the National School of Biological Sciences of the Instituto Politécnico Nacional and the Herbarium (CMMEX) of the Faculty of Marine Sciences of the Universidad Autónoma de Baja California (Holmgren et al. 1990). For descriptive terminology we followed Segawa (1941), Denizot (1968), and Moura and Yamaguishi-Tomita (1998).

\section{RESULTS AND DISCUSSION}

Jania ungulata (Yendo) Yendo f. brevior (Yendo) Yendo 1905: 38

\section{(Fig. 2)}

Basionym: Corallina ungulata Yendo f. brevior Yendo (1902: 27)

Type locality: Boshu Province, Chiba, Japan.

Distribution: Indian Ocean (Kenya, India, Tanzania, Seycheles Archipelago and Mauricio Islands) (Silva et al. 1996). Atlantic Ocean (Brazil) (Moura and YamaguishiTomita 1998). Pacific Ocean (Colombia and Galapagos islands). Asia (China, Japan, Korea, Philippines and Vietnam) (Silva, Basson and Moe 1996, Lee and Kang 2001, Sahoo et al. 2001) and Pacific coast of Mexico (present study).

Specimens examined: Baja California Sur. Punta Conejo, 5.XII.1992, L.E. Mateo-Cid and C. MendozaGonzález (ENCB 14204); Jalisco. Playa El Corral,
24.V.1970, L. Huerta Múzquiz (ENCB 13064): Colima. Playa La Audiencia, Manzanillo, 27.VII.1988, L.E. MateoCid and C. Mendoza-González (ENCB 14205); Guerrero. Playa Las Gatas, Bahía de Zihuatanejo, 8.XI.1996, C. Mendoza-González and L.E. Mateo-Cid (ENCB 15782). Oaxaca. Playa Santa Elena, 8.V.1998, L.E. Mateo-Cid and C. Mendoza-González (ENCB 17138).

Thallus were commonly growing epiphytes in Padina sp. in tidal pools on the rocky intertidal zone, having pinkish thalli, consisted of articulated erect, delicate fronds, to $1.2 \mathrm{~cm}$ tall (Fig. 2A), arising from diminutive, calcified semi-circular crustose bases. Fronds were dichotomously branched in a single plan, show the Ypatterns and with open branches at less than a $45^{\circ}$ angle. Intergenicula terete, with lower and middle branches and terminals bearing ungulate apices, flattened. Tetrasporangial conceptacles were axial with a pore and ramulus of 2-4 terete intergenicula. Tetrasporangia are zonate, $80-110 \mu \mathrm{m}$ long and $25-50 \mu \mathrm{m}$ in diameter.

The genus Jania was established by Lamouroux (1812) and consists of about 70 species (Johansen and Womersley, 1994), characterized by an articulated thallus with dichotomous branching; filiform and slender intergenicula, cell filaments interconnected by cell fusions and the conceptacles axial and uniporate, carrying ramulus, except in the male (Johansen 1970; Johansen and Forest 1978).

There are 12 species of Jania reported from the Mexican Pacific coast (Dawson 1953). However, many of these have been reported in floristic lists or ecological publications and need to be analyzed in detail to distinguish different taxa. In the present study, Jania ungulata is registered for the first time to Mexico and recognized as a typical element of the tropical flora, as in other areas of the world (Silva et al. 1996; Moura and YamaguishiTomita 1998; Sahoo et al. 2001).

The absence of records of Jania ungulata f. brevior along the Pacific coast of Mexico may be related in part to the lack of specific collections along the coast and in part to the difficulty in locating this species due to the small size of the thallus (Mendoza-González and Mateo-Cid 1992; Moura and Yamaguishi-Tomita 1998).

\section{Peyssonnelia japonica (Segawa) Yoneshigue 1984: 134} (Fig. 3)

Basionym: Cruoriopsis japonica Segawa (1941: 259-260)

Synonym: Cruoriella japonica (Segawa) Denizot (1968: 147)

Type locality: Miyake-zima, Japan 


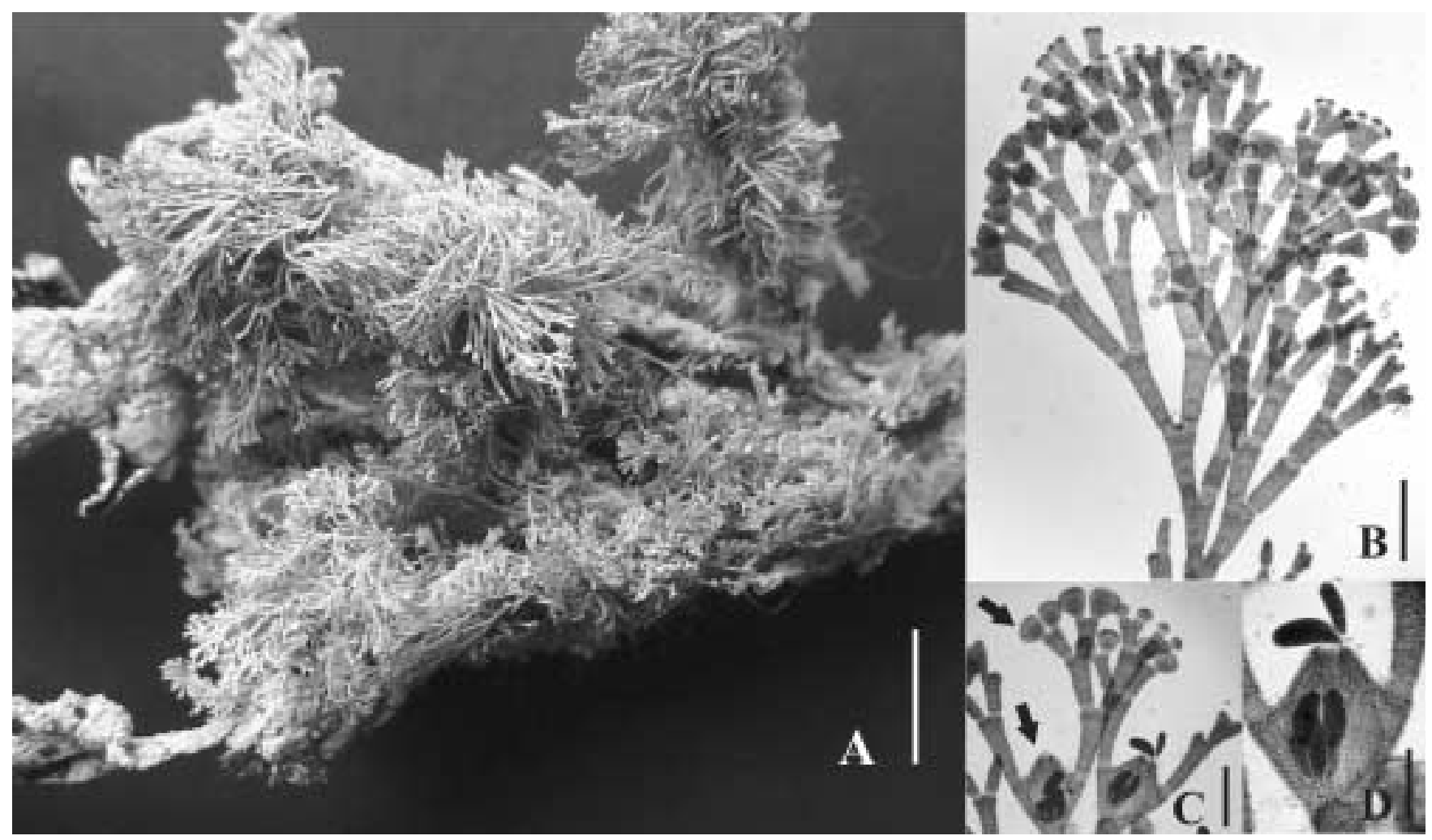

Fig. 2. Jania ungulata (Yendo) Yendo f. brevior (Yendo) Yendo. A. Specimen collected on Padina sp. from Playa Santa Elena, Oaxaca (ENCB 17138). B. Detail of dichotomously branched. C. Detail of apical intergenicula and conceptacle (arrowheads). D. Detail of tetrasporangial conceptacle. (Scale: A, $1.0 \mathrm{~cm} ; \mathrm{B}, 450 \mu \mathrm{m} ; \mathrm{C}, 350 \mu \mathrm{m} ; \mathrm{D}, 150 \mu \mathrm{m}$ ).

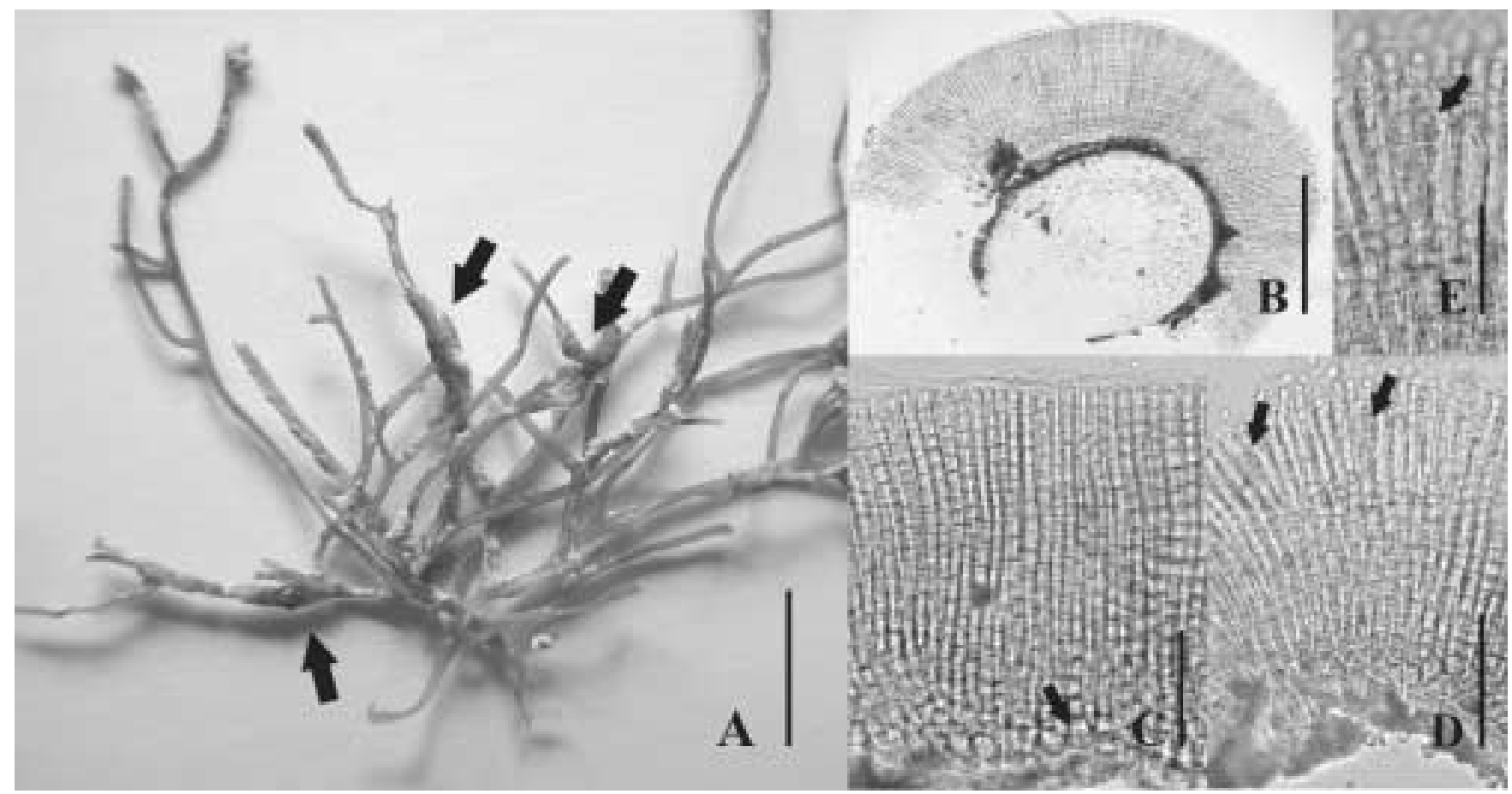

Fig. 3. Peyssonnelia japonica (Segawa) Yoneshigue. A. Specimen (arrowheads) growing on Gelidiopsis variabilis collected in Puerto Peñasco, Sonora (ENCB 17137). B. Vegetative crust in vertical section. C. Vertical section showing the basal layer (arrowheads). D. Cross-section of the frond showing ripe sporangia (arrowheads). E. Detail of tetrasporangial nemathecium. (Scale: $\mathrm{A}, 1.5 \mathrm{~cm}$; $\mathrm{B}, 300 \mu \mathrm{m} ; \mathrm{C}, 70 \mu \mathrm{m} ; \mathrm{D}, 70 \mu \mathrm{m} ; \mathrm{E}, 40 \mu \mathrm{m})$. 
Distribution: Asia: Korea and Japan (Yoshida 1998, Lee and Kang 2001, Kato et al. 2006) and Pacific coast of Mexico (present study).

Specimens examined: Sonora. Puerto Peñasco, 10.III.1997, C. Mendoza-González, L.E. Mateo-Cid, L.E. Aguilar-Rosas and R. Aguilar-Rosas, tetrasporangia (ENCB 17137).

Thallus grew epiphytically on Gelidiopsis variabilis (J. Agardh) Schmitz in tidepools. Were pinkish, crustose, 180-220 $\mu \mathrm{m}$ thick, attached completely to the lower surface, and sometimes developed small rhizoids. The basal layer was 2 cells of thick, with the lower cells 10-16 $\mu \mathrm{m}$ wide and 16-20 $\mu \mathrm{m}$ high and the upper cells smaller than the lower, with trapezoidal in longitudinal sections. Erect filaments arose from the upper cells of the basal layer, divided into a large number near the base that were rarely dichotomous above, and consisted of 10-16 cells. Cells in the filament were cubic or little elongated 6-8 $\mu \mathrm{m}$ wide and 8-12 $\mu \mathrm{m}$ high in the middle portion of the filaments. Tetrasporangia were cruciately divided, stalked, and oblong and 25-50 $\mu \mathrm{m}$ long and $16-25 \mu \mathrm{m}$ in diameter. The stalk of the tetrasporangia was lateral on the erect filament, consisting of 1-5 cells.

The genus Peyssonnelia M.J. Decaisne (1841) consists of about 71 species (Guiry and Guiry 2007), and is characterized by thalli that are prostrate, crustose, and tightly adherent to loosely attached. A single basal layer of branched filaments (hypothallus) is composed of parallel or flabellate rows, and produces unicellular or multicelular rhizoids below. The hypothallus cuts off single cells that form erect filaments (perithallus). Tetrasporangia are cruciately divided and form in nemathecia with numerous paraphyses. Denizot (1968) considered the genera Peyssonnelia and Cruoriella to be distinct, with Cruoriella having easily separable erect filaments in a gelatinous matrix and Peyssonnelia having closely adjacent erect filaments in a firm matrix. However, in accordance with Yoneshigue (1984), Maggs (1990), and Womersley (1994), Cruoriella is considered not generically distinct from Peyssonnelia. The new combination of Cruoriella japonica to the genus Peyssonnelia (P. japonica) was proposal by Yoneshigue (1984).

Peyssonnelia japonica is known only from Japan (Segawa 1941) and Korea (Lee and Kang 2001). In the Mexico Pacific coast, 14 species of Peyssonnelia, were reported (Dawson 1953). In the present paper, $P$. japonica is registered for the first time for Mexico extending the geographical distribution of this species to the western coast of North America (Segawa 1941; Denizot 1968;
Yoneshigue 1984).

The vegetative and reproductive structures of our specimens, agree with the descriptions and illustrations of P. japonica by Segawa (1941) as Cruoriopsis japonica and by Denizot (1968) as Cruoriella japonica. This species differs from the other described species by the presence of rhizoids, by the basal layer composed of trapezoidal cells, by the erect filaments divided near the base consisting of many cells which are comparatively narrow, cubic or slightly extended, and the comparatively large tetrasporangia, located sideways on the erect filaments.

We looked other specimens of Gelidiopsis sp. deposited in the herbarium ENCB and CMMEX, unfortunately Peyssonnelia japonica was not present. The absence of records of Peyssonnelia japonica in the Mexican Pacific coast is likely related to the fact that these have been few studies in the region and the fact that the specimens are small and delicate, and may commonly be unnoticed during samplings (Aguilar-Rosas et al. 2000).

\section{ACKNOWLEDGEMENTS}

The authors wish to thank the Facultad de Ciencias Marinas and Instituto de Investigaciones Oceanológicas of the Universidad Autónoma de Baja California and Escuela Nacional de Ciencias Biológicas of the Instituto Politécnico Nacional for supporting this research. The fourth author is grateful for the scholarship granted by the Comisión de Operacion y Fomento de Actividades Académicas del IPN (COFAA) of the IPN. Special thanks to Benjamin Ruttenberg for the English translation.

\section{REFERENCES}

Aguilar-Rosas L.E., Aguilar-Rosas R.A., Mendoza-González A.C. and Mateo-Cid L.E. 2000. Marine algae from the Northeast coast of Baja California, México. Bot. Mar. 43: 127-139.

Aguilar-Rosas R., Aguilar-Rosas L.E., Avila-Serrano G. and Marcos-Ramírez R. 2004. First record of Undaria pinnatifida (Harvey) Suringar (Laminariales, Phaeophyta) on the Pacific coast of Mexico. Bot. Mar. 47: 255-258.

Aguilar-Rosas R., Aguilar-Rosas L.E. and Pedroche F.F. 2005. Ulva fasciata Delile (Ulvaceae, Chlorophycota): a species newly introduced into Pacific Mexico. Bot. Mar. 48: 46-51.

Broom J.E., Nelson W.A., Yarish C., Jones W.A., Aguilar-Rosas R. and Aguilar-Rosas L.E. 2002. A reassessment of the taxonomic status of Porphyra suborbiculata, Porphyra carolinensis and Porphyra lilliputiana (Bangiales, Rhodophyta) based on molecular and morphological data. Eur. J. Phycol. 37: 227235. 
Dawson E.Y. 1944. The marine algae of the Gulf of California. A. Hancock Pac. Exped. 3: 189-453.

Dawson E.Y. 1953. Resumen de las investigaciones recientes sobre algas marinas de la costa Pacífica de México, con una sinopsis de la literatura, sinonímia y distribución de las especies descritas. Rev. Soc. Mex. Hist. Nat. 13: 97-197.

Guiry M.D. and Guiry G.M. 2007. AlgaeBase version 4.2. World-wide electronic publication, National University of Ireland, Galway. http:/ /www.algaebase.org, searched on 14 February 2007.

Holmgren P.K., Holmgren N.H. and Barnett I.C. 1990. Index Herbariorum, Pt 1: The Herbaria of the World, $8^{\text {th }}$ ed. New York Botanical Garden, New York, Bronx. x + 693 p. [Regnum Vegetabile, vol. 20].

Kato A., Baba M., Kawai H. and Masuda M. 2006. Reassessment of the little-known crustose red algal genus Polystrata (Gigartinales), based on morphology and SSU rDNA sequences. J. Phycol. 42: 922-933

Lee Y.P. and Kang S.Y. 2001. A Catalogue of the Seaweeds in Korea. Cheju National University Press, Jeju, Korea.

Martoja R. and Martoja-Pierson M. 1970. Técnicas de histología animal. Barcelona, Toray-Masson.

Mateo-Cid L.E., Mendoza-González A.C., Gavio B. and Fredericq S. 2005. Grateloupia huertana sp. nov. (Halymeniaceae, Rhodophyta), a peculiar new prostrate species from tropical Pacific Mexico. Phycologia 44: 4-16.

Mendoza-González A.C. and Mateo-Cid L.E. 1992. La familia Corallinaceae (Rhodophyta, Corallinales) en la Península de Baja California. In: Siqueiros-Beltrones D.S. (ed.), Memorias del IX Simposium Internacional de Biología Marina.
Universidad Autónoma de Baja California Sur, La Paz. pp 49-53.

Moura C.W.N. and Yamaguishi-Tomita N. 1998. Jania ungulata f. brevior (Corallinales, Rhodophyta): nova ocorrencia para o Atlnatico. Hidrobiológica 8: 145-153.

Pedroche F.F. and Sentíes G.A. 2003a. El litoral del Pacífico mexicano y su exploración ficológica. In: Robledo D., Godínez J.L. and Freile Y. (eds), Contribuciones Ficológicas de México. Sociedad Ficológica de México, A.C., Mérida. pp. 511.

Pedroche F.F. and Sentíes G.A. 2003b. Ficología marina mexicana. Diversidad y Problemática actual. Hidrobiológica 13: 23-32.

Segawa S. 1941. New or noteworthy algae from Izu. Sci. Pap. Inst. Algol. Res., Fac. Sci. Hokkaido Univ. 2: 251-271.

Silva P.C., Basson P.W. and Moe R.L. 1996. Catalogue of the benthic marine algae of the Indian Ocean. Univ. of Calif. Publ. Bot. 79: 1259.

Yendo K. 1902. Coralline Verae Japonicae. Jour. Coll. Sci. Imp. Univ. Tokyo 12: 1-36.

Yendo K. 1905. A revised list of Coralline. Jour. Coll. Sci. Imp. Univ. Tokyo 20: 1-46.

Yoneshigue Y. 1984. Flore marine de la région de Cabo Frio (Brasil). 4. Sur une espèce nouvelle du genre Peyssonnelia (Cryptonemiales: Rhodophyta). Vie et Milieu 34: 133-137.

Yoshida T. 1998. Marine algae of Japan. Tokyo: Uchida Rokakuho Publishing. pp. $25+1222$.

Received 17 July 2007

Accepted 3 September 2007 
